\title{
Effect of Citric Acid, Phytase and Calcium Levels on the Calcium and Phosphorus Content in Egg: Yolk-Albumen and Shell, Yolk Color and Egg Quality in Diets of Laying Hens
}

\author{
Lily M. Vargas-Rodríguez ${ }^{*}$, Jesús E. Morales-Barrera², José G. Herrera-Haro1, Juan Antonio-Bautista ${ }^{3}$, \\ Roberto López-Pozos ${ }^{4}$, David Hernández-Sánchez ${ }^{1}$
}

\begin{abstract}
${ }^{1}$ Instituto de Recursos Genéticos y Productividad (IREGEP), Colegio de Postgraduados, Texcoco, México
${ }^{2}$ Departamento de Medicina Veterinaria y Zootecnia, Universidad Autónoma Metropolitana, Xochimilco, D.F. México, México

${ }^{3}$ División de Ingeniería en Procesos Bioalimentarios, Universidad Tecnológica de los Valles Centrales de Oaxaca, Oaxaca, México

${ }^{4}$ Licenciatura en Zootecnia, Universidad del Mar. Puerto Escondido, Oaxaca, México

Email: *livarrod@gmail.com
\end{abstract}

How to cite this paper: Vargas-Rodríguez, L.M., Morales-Barrera, J.E., Herrera-Haro, J.G., Antonio-Bautista, J., López-Pozos, R. and Hernández-Sánchez, D. (2016) Effect of Citric Acid, Phytase and Calcium Levels on the Calcium and Phosphorus Content in Egg: Yolk-Albumen and Shell, Yolk Color and Egg Quality in Diets of Laying Hens. Food and Nutrition Sciences, 7, 1364-1374. http://dx.doi.org/10.4236/fns.2016.714124

Received: August 17, 2016

Accepted: December 6, 2016

Published: December 9, 2016

Copyright $\odot 2016$ by authors and Scientific Research Publishing Inc. This work is licensed under the Creative Commons Attribution International License (CC BY 4.0).

http://creativecommons.org/licenses/by/4.0/ (c) $\underset{\mathrm{EY}}{ }$ Open Access

\begin{abstract}
To evaluate the effect of different levels of citric acid (CA) combined with phytase and calcium levels in the diets of laying hens on the calcium and phosphorus (P) contents of eggs: yolk-albumen and shell, yolk color and egg quality. A study was conducted with 24-week-old laying hens fed with a diet based on sorghum and soybean meal with $2.7 \mathrm{Mcal}$ of EM/kg, $15 \%$ crude protein, $3.25 \%$ calcium and $0.25 \%$ available $\mathrm{P}$. The levels of CA, phytase and calcium were $0 \%, 0.6 \%$ and $1.2 \% ; 0$ and 300 units of phytase (PHYU)/kg; and 3.0\% and 3.25\%, respectively. Phytase was added as an ingredient into to the diets, contributing $0.1 \% \mathrm{P}$ and $0.3 \%$ calcium. A completely randomized factorial experiment was performed with a $3 \times 2 \times 2$ design and 4 replications. The CA increased $(\mathrm{P}<0.05)$ the $\mathrm{P}$ in the shell, and the combination of $1.2 \% \mathrm{CA}, 300 \mathrm{PHYU}$ phytase and $3.25 \%$ calcium increased $(\mathrm{P}<0.05)$ the calcium in the eggshell. There was a CA $\times$ phytase $\times$ calcium interaction $(\mathrm{P}<0.05)$ affecting egg yolk pigmentation; there were no differences in egg quality. It was concluded that adding CA to the diets of laying hens increases eggshell calcium content, and improves the phytase response. $1.2 \% \mathrm{CA} \times$ Phytase $\times 3.25 \%$ calcium significantly increases shell calcium by $0.56 \mathrm{~g}$. Under the conditions of the present investigation, it would imply greater resistance of the eggs to be broken in the handling from the farm to the sales centers and consumer. Phytase interacts negatively with $0.6 \% \mathrm{CA}$ at low calcium levels to degrade the yellow pigmentation of the yolk.
\end{abstract}




\section{Keywords}

Citric Acid, Phytase, Calcium, Laying Hens, Eggshell

\section{Introduction}

The phytic acid (myoinositol hexaphosphate) present in vegetable seeds reduces the availability of phosphorus $(\mathrm{P})$ and, at a certain $\mathrm{pH}$ interferes with the dispensability of minerals [1], which are excreted into the environment. This, in turn, constitutes a global ecological problem.

Studies show that phytase improves P availability [2] [3] [4] [5] [6], but a determining factor in phytic acid hydrolysis is $\mathrm{pH}$. The ability of phytic acid to chelate at alkaline $\mathrm{pH}$ is strong, and it forms insoluble salts with different minerals [1].

Studies show that citric acid (CA) reduces the chelation potential of phytic acid by binding to certain minerals, which results in lower excretion and greater availability of $\mathrm{P}$, calcium and nitrogen [7]-[13].

However, high levels of calcium and a neutral $\mathrm{pH}$ allow calcium to bind to phytic acid and form calcium phytate salt, an insoluble compound, which makes calcium unavailable to laying hens and as well as inaccessible to phytase [14]. Although many factors influence the percentage of broken eggs, the nutrition is an important factor. The egg shell, composed of $94 \%$ of calcium carbonate, has an economic impact on the poultry industry; on average the percentage of broken eggs oscillates in $8 \%$ of the production, which represents great economic losses.

In a study of the effects of CA combined with phytase excretion and availability of calcium and $\mathrm{P}$ in the diets of molting laying hens, it is concluded that $2 \% \mathrm{CA}$ increases the content of calcium in the shell and $\mathrm{P}$ in the yolk-albumen of the egg, and reduces $\mathrm{N}$ excretion; and 2\% CA combined with 600 phytase units (PHYU) reduces $\mathrm{P}$ excretion and increases egg weight [9].

The above led to the proposed study with the following objectives: 1) evaluate the effect of CA on the calcium and P content of the egg including the yolk-albumen and shell, pigmentation of the yolk and the quality of the egg; 2) evaluate the effect of CA on the phytase response in diets of laying hens from the ages of 24 to 39 weeks; 3 ) evaluate the effects of the diets on egg calcium and $\mathrm{P}$ contents in the yolk-albumen, shell, pigmentation of the yolk and egg quality in laying hens aged 24 to 39 weeks.

\section{Materials and Methods}

The research was carried out at INIFAP's "Valle de México" experimental station inChapingo, Mexico. One hundred and forty-four Hy-line W98 24-week-old hens were housed in individual metal cages with automatic feed and water troughs. The hens were evaluated for 15 weeks and provided with 12 hours of natural light in addition to a sufficient duration of artificial light to attain 17 hours of total light during the peak laying period. 
Diets were based on sorghum + soybean meal, with a $15 \%$ protein, $0.25 \%$ available phosphorus and 3.25\% calcium and a total of $2.7 \mathrm{Mcal} \mathrm{EM} / \mathrm{kg}$ (Table 1).

Diet components were analyzed and $\mathrm{N}$ was determined through Kjeldahl's method, $\mathrm{P}$ by spectrophotometry ${ }^{1}$ and calcium by atomic absorption ${ }^{2}$ [15].

Sixty grams/t of phytase was added to the diet, and phytase was considered as a diet's ingredient based on the dose to be used, 300 PHYU (phytase unit) and on its potential product, Natuphos $5000^{3}$. One phytase unit (PHYU) is defined as the amount of enzyme activity that liberates $1 \mathrm{mmol}$ of inorganic $\mathrm{P} /$ minute from a $0.5 \mathrm{mM} \mathrm{Na}$-phytate solution

Table 1. Composition of the basal diet fed to laying hens from 24 to 39 week of age .

\begin{tabular}{|c|c|}
\hline Ingredient & $\%$ \\
\hline Sorghum & 73.5700 \\
\hline Soy bean & 14.5600 \\
\hline Calcium carbonate & 9.1300 \\
\hline Orthophosphate & 1.8000 \\
\hline Salt & 0.3500 \\
\hline DL-Methionine & 0.1500 \\
\hline Vitamin Premix $\dagger$ & 0.1000 \\
\hline Mineral Premix $\ddagger$ & 0.1000 \\
\hline Oil & 0.1000 \\
\hline L-Lysine & 0.1400 \\
\hline Pigment & 0.0015 \\
\hline \multicolumn{2}{|l|}{ Calculated nutrient } \\
\hline Crude protein & 15.00 \\
\hline Metabolizable Energy (Mcal/Kg) & 2.7 \\
\hline Lysine & 0.690 \\
\hline Methionine + Cysteine & 0.580 \\
\hline Threonine & 0.470 \\
\hline Calcium & 3.250 \\
\hline Nonphytate Phosphorus (AP) & 0.250 \\
\hline Total Phosphorus (TP) & 0.500 \\
\hline
\end{tabular}

${ }^{*}$ The dietary treatments were: $0.0 \%$ CA, 0.0 PHYU, 3.25\% Ca; 0.0\% CA, 0.0 PHYU, 3.00\% Ca; $0.0 \%$ AC, 300 PHYU, $3.00 \%$ Ca; 0.0\% CA, 300.0 PHYU, 3.25\% Ca; 0.6\% CA, 0.0 PHYU, 3.00\% Ca; 0.6\% CA, 0.0 PHYU, 3.25\% Ca; 0.6\% CA, 300 PHYU, 3.00\% Ca; 0.6\% CA, 300 PHYU, 3.25\% Ca; $1.2 \%$ CA, 0.0 PHYU, 3.00\% Ca; $1.2 \%$ CA, 0.0 PHYU, $3.25 \%$ Ca; $1.2 \%$ CA, 300 PHYU, 300\% Ca; and 1.2\% CA, 300 PHYU, 3.25\% Ca. Citric acid and phytase were added at the expense of sorghum. Phytase was added as a dietary ingredient to relevant treatments based on the dose of 300 PHYU and on its potential product, Natuphos 5000 (BASF, México, D.F). For diets containing phytase, the P and calcium levels were subtracted from the orthophosphate concentrations. Phytase leads to the release of approximately $0.1 \% \mathrm{P}$ and $0.3 \%$ calcium (Parr, 1996). †Vitamin premix per kg of feed: A (retinol), 12,000 IU; D (cholecalciferol), $2400 \mathrm{IU}$; E (DL-alpha-tocopherol), $20 \mathrm{IU}$; K (menadione), $1.2 \mathrm{mg}$; thiamine, $1.6 \mathrm{mg}$; riboflavin, $8.0 \mathrm{mg}$; niacin, 32 $\mathrm{mg}$; pyridoxine $3 \mathrm{mg}$; pantothenic acid, $11.2 \mathrm{mg}$; cyanocobalamin, $16 \mu \mathrm{g}$; folic acid, $1.6 \mathrm{mg}$; choline, $250 \mathrm{mg}$. ¥Mineral premix per kg of feed: $\mathrm{Mn}, 60 \mathrm{mg} ; \mathrm{Zn}, 50 \mathrm{mg} ; \mathrm{Fe}, 30 \mathrm{mg}, \mathrm{Cu}, 5 \mathrm{mg} ; \mathrm{I}, 1.0 \mathrm{mg}$; Se, $0.1 \mathrm{mg}$.

${ }^{1}$ Genesys 10SUV-VIS, Madison, Wisconsin, USA.

${ }^{2}$ Varian Spectra Inc. AA 240 FS. Palo Alto, CA, USA.

${ }^{3}$ BASF, D.F, Mexico. 
at $\mathrm{pH} 5.5$ and $37.5^{\circ} \mathrm{C} . \mathrm{P}$ and $\mathrm{Ca}$ values freed through phytase's action were approximately $0.1 \%$ and $0.3 \%$ [16].

Food grade anhydrous CA was added to the experimental diets. The diet's $\mathrm{pH}$ was determined on a $20 \mathrm{~g}$ sample by means of a potentiometer at the start, midway point and final stage of the experiment.

\subsection{Variables Measured}

Egg quality in Haugh units (HU) was determined every 2 weeks. Albumen height was measured with a micrometer and estimated with the following equation [17]:

$$
\mathrm{HU}=100 \log \mathrm{H}
$$

where $\mathrm{H}=\mathrm{h}+\left(7.685-1.7 \mathrm{~W}^{0.37}\right)$;

$\mathrm{h}=$ observed albumen height $(\mathrm{mm})$, and $\mathrm{W}=$ egg weight.

The specific gravity was measured with a hydrometer every 2 weeks. The values in the solutions ranged from 1.068 to 1.100 with an increase of 0.004 .

The color and brightness of the egg was measured twice with a reflectance colorimeter: once halfway through the experiment and once at the end.

$\mathrm{P}$ content in the yolk-albumen, eggshell, and diets was determined colorimetrically; calcium content was determined by atomic absorption; and $\mathrm{N}$ content was determined by the Kjeldahl method [15].

At 60 and 110 days, which were the first and second sampling days, respectively, 4 hens per treatment were selected to assess the calcium and $\mathrm{P}$ contents of the yolk-albumen and shell, and these samples were collected each day for 3 days. Subsequently, the shell and the yolk-albumen were separated and dried at $55^{\circ} \mathrm{C}$ and the samples were incinerated for the corresponding analyses.

The ashes obtained from the samples were solubilized with 50\% and 10\% HC land evaporated to a volume not less than $10 \mathrm{ml}$, and the solution was transferred to $50-\mathrm{ml}$ volumetric flasks for subsequent dilution. Molybdic acid and p-methylaminophenol sulfate, were used to determine the $\mathrm{P}$ content, and dilutions were made depending on the part of the egg to be analyzed. The samples were then read in a UV spectrophotometer at $660 \mathrm{~nm}$. To determine calcium, lanthanum oxide was used, and the dilutions were made according to the part of the egg to be analyzed. Samples were then read by atomic absorption spectrophotometry at a wavelength of $425 \mathrm{~nm}$.

\subsection{Statistical Analyses}

Treatments were randomly assigned to the experimental units according to a completely randomized factorial design with a $3 \times 2 \times 2$ arrangement: 3 levels of CA ( $0 \%$, $0.6 \%$ and 1.2\%), 2 levels of phytase ( 0 and 300 PHYU) and 2 levels of calcium (3.0\% and $3.25 \%)$ with 4 replicates per treatment and 3 hens per replicate. The means were compared using Tukey's test [18], and the data were analyzed using the program SAS [19].

\section{Results and Discussion}

There were no differences $(\mathrm{P}>0.05)$ in productive performance: feed consumption, 
feed conversion, egg weight and egg production (data not shown).

\subsection{Phosphorus and Calcium Content in Eggs: Yolk-Albumen and Shell}

There were no significant differences $(\mathrm{P}>0.05)$ in the $\mathrm{P}$ and calcium contents of the yolk-albumen (Table 2). However, [9] in their study of molting laying hens, found an effect of CA and phytase on $\mathrm{P}$ and calcium, respectively, in yolk-albumen of egg; factors such as age and physiological state of the birds affect the response, in molting birds, calcium metabolism and its deposition in the egg increases [20]. Other important factors include the genetic line, diets, among others.

For $\mathrm{P}$ content in the shell, $1.2 \% \mathrm{CA} \times 300 \mathrm{PHYU} \times 3.25 \%$ calcium, $1.2 \% \mathrm{CA} \times 0$ $\mathrm{PHYU} \times 3.0 \%$ calcium and $0.6 \% \mathrm{CA} \times 300 \mathrm{PHYU} \times 3.0 \%$ calcium, increased the amount of $\mathrm{P}$ in the shell $(\mathrm{P}<0.05)$ to $0.0067,0.0067$ and $0.0065 \mathrm{~g}$ respectively, in contrast with $0.0 \% \mathrm{CA} \times 300 \mathrm{PHYU} \times 3.0 \%$ calcium and $0.6 \% \mathrm{CA} \times 0 \mathrm{PHYU} \times 3.0 \%$ calcium with 0.0041 and $0.0040 \mathrm{~g}$ respectively (Table 3).

CA linearly increased the calcium content in the shell $(\mathrm{P}<0.05)$ from 1.72 to 1.97 , and $2.0 \mathrm{~g}$ for $0 \%, 0.6 \%$ and $1.2 \%$ respectively (Table 3 ). $1.2 \% \mathrm{CA} \times 300 \mathrm{PHYU} \times 3.25 \%$ calcium diets increased the eggshell calcium content $(\mathrm{P}<0.05)$ to $2.25 \mathrm{~g}$, in contrast with $0 \% \mathrm{CA} \times 0 \mathrm{PHYU} \times 3.0 \%$ and $3.25 \%$ calcium and the $0 \% \mathrm{CA} \times 300 \mathrm{PHYU} \times 3 \%$ calcium with $1.68,1.69$ and $1.72 \mathrm{~g}$ respectively (Table 3 ).

The $\mathrm{pH}$ of the diets with addition of CA decreased, from 5.4 in the control group to

Table 2. Phosphorus and calcium contents in the egg yolk-albumen (g/hen/day) in 24 to 39 week-old hens supplemented with citric acid, phytase and calcium*.

\begin{tabular}{lcccc}
\hline & \multicolumn{3}{c}{ Sample } \\
\cline { 2 - 5 } Variable & \multicolumn{3}{c}{ First } & \multicolumn{3}{c}{ Second } \\
\cline { 2 - 5 } CA $\times$ PHYU $\times$ Ca & $\mathrm{P}$ & $\mathrm{Ca}$ & $\mathrm{P}$ & $\mathrm{Ca}$ \\
\hline 0.003 .00 & & & & \\
0.003 .25 & 0.107 & 0.036 & 0.104 & 0.032 \\
0.03003 .00 & 0.111 & 0.037 & 0.106 & 0.032 \\
0.03003 .25 & 0.113 & 0.038 & 0.101 & 0.031 \\
0.60 .03 .00 & 0.103 & 0.035 & 0.099 & 0.029 \\
0.60 .03 .25 & 0.110 & 0.034 & 0.108 & 0.029 \\
0.6303 .00 & 0.095 & 0.028 & 0.099 & 0.031 \\
0.63003 .25 & 0.093 & 0.033 & 0.106 & 0.033 \\
1.20 .03 .00 & 0.115 & 0.041 & 0.105 & 0.034 \\
1.20 .03 .25 & 0.107 & 0.037 & 0.104 & 0.030 \\
1.23003 .00 & 0.091 & 0.032 & 0.108 & 0.034 \\
1.23003 .25 & 0.099 & 0.035 & 0.097 & 0.028 \\
SE & 0.101 & 0.032 & 0.096 & 0.032 \\
\hline
\end{tabular}

${ }^{\star}$ No interaction. $\mathrm{CA}=$ citric acid; $\mathrm{Ca}=$ calcium; $\mathrm{P}=$ phosphorus. $\mathrm{SE}=$ standard error. 
Table 3. Phosphorus and calcium contents in the eggshell (g/hen/day) of 24 to 39 week-old laying hens supplemented with citric acid, phytase and calcium.

\begin{tabular}{|c|c|c|c|c|}
\hline \multirow{3}{*}{ Variable } & \multicolumn{4}{|c|}{ Sample } \\
\hline & \multicolumn{2}{|c|}{ First } & \multicolumn{2}{|c|}{ Second } \\
\hline & $\mathrm{P}$ & $\mathrm{Ca}$ & $\mathrm{P}$ & $\mathrm{Ca}$ \\
\hline \multicolumn{5}{|l|}{ Citric acid (\%) } \\
\hline 0.0 & 0.0052 & $1.73^{\mathrm{b}}$ & $0.0049^{\mathrm{b}}$ & $1.72^{\mathrm{b}}$ \\
\hline 0.6 & 0.0048 & $1.92^{\mathrm{ab}}$ & $0.0051^{\mathrm{b}}$ & $1.97^{\mathrm{a}}$ \\
\hline 1.2 & 0.0050 & $2.03^{\mathrm{a}}$ & $0.0061^{\mathrm{a}}$ & $2.00^{\mathrm{a}}$ \\
\hline \multicolumn{5}{|l|}{ Phytase (PHYU) } \\
\hline 0 & 0.0051 & 1.83 & $0.0051^{\mathrm{b}}$ & 1.91 \\
\hline 300 & 0.0049 & 1.94 & $0.0057^{\mathrm{a}}$ & 1.90 \\
\hline \multicolumn{5}{|l|}{ Calcium (\%) } \\
\hline 3.0 & 0.0051 & 1.94 & 0.0055 & 1.92 \\
\hline 3.25 & 0.0049 & 1.84 & 0.0052 & 1.89 \\
\hline \multicolumn{5}{|c|}{$\mathrm{CA} \times \mathrm{PHYU} \times \mathrm{Ca}$} \\
\hline 0.00 .03 .00 & 0.0053 & 1.57 & $0.0054^{\mathrm{abc}}$ & $1.68^{\mathrm{b}}$ \\
\hline 0.00 .03 .25 & 0.0050 & 1.63 & $0.0054^{\mathrm{abc}}$ & $1.69^{\mathrm{b}}$ \\
\hline 0.03003 .00 & 0.0050 & 1.80 & $0.0041^{\mathrm{bc}}$ & $1.72^{\mathrm{b}}$ \\
\hline 0.03003 .25 & 0.0054 & 1.82 & $0.0049^{\mathrm{abc}}$ & $1.77^{\mathrm{ab}}$ \\
\hline 0.60 .03 .00 & 0.0050 & 1.79 & $0.0040^{c}$ & $2.05^{\mathrm{ab}}$ \\
\hline 0.60 .03 .25 & 0.0052 & 1.83 & $0.0044^{\mathrm{abc}}$ & $1.91^{\mathrm{ab}}$ \\
\hline 0.63003 .00 & 0.0051 & 1.92 & $0.0065^{\mathrm{a}}$ & $2.05^{\mathrm{ab}}$ \\
\hline 0.63003 .25 & 0.0041 & 2.12 & $0.0057^{\mathrm{abc}}$ & $1.89^{\mathrm{ab}}$ \\
\hline 1.20 .03 .00 & 0.0056 & 1.96 & $0.0067^{\mathrm{a}}$ & $2.19^{\mathrm{ab}}$ \\
\hline 1.20 .03 .25 & 0.0045 & 2.08 & $0.0044^{\mathrm{abc}}$ & $1.81^{\mathrm{ab}}$ \\
\hline 1.23003 .00 & 0.0047 & 1.91 & $0.0064^{\mathrm{ab}}$ & $1.99^{\mathrm{ab}}$ \\
\hline 1.23003 .25 & 0.0051 & 2.17 & $0.0067^{\mathrm{a}}$ & $2.25^{\mathrm{a}}$ \\
\hline SE & 0.0005 & 0.12 & 0.0005 & 0.11 \\
\hline
\end{tabular}

${ }_{\mathrm{a}, \mathrm{b}, \mathrm{c}}$ Averages with distinct letters within columns are significantly different $(\mathrm{p} \leq 0.05)$. CA = citric acid; $\mathrm{Ca}=$ calcium; $\mathrm{P}=$ phosphorus. $\mathrm{SE}=$ standard error.

4.7 and 4.3 with $0.6 \%$ and $1.2 \%$ CA, respectively, which most likely acidified the gastrointestinal tract as indicated by [21] [22]. For phytase [23] conclude that the addition of phytase increases the $\mathrm{pH}$ of the gastrointestinal tract, gizzard, duodenum, jejunum and ileum, which would affect the solubility of calcium, as calcium solubility depends on the chemical form of the calcium salts and the $\mathrm{pH}$ in the intestinal region [24]. Citric acid improved the phytase response, making calcium more available, with greater calcium deposition in the shell.

The addition of CA could promote calcium solubility by creating an acidic environment in the gastrointestinal tract that facilitates the absorption of calcium ions, thus 
decreasing calcium excretion increasing its availability. This is supported by [13] in their study of laying hens as well as by the higher calcium content in the shell observed in the present study. Calcium is completely soluble under an acidic $\mathrm{pH}$ and does not bind to phytic acid [25].

On the other hand [26] increased calcium levels from $2.5 \%$ to $3.5 \%$ and $4.5 \%$ in the diets of laying eggs observed a significant improvement in shell quality; therefore, birds supplemented with higher levels of calcium retained more of this mineral for shell composition.

In terms of phytase, in a study with laying hens in the tropics, [27] indicate that phytase does not affect shell parameters, [3] [28] find that eggshell quality tends to decrease in hens fed phytase. In the current study, 0\% CA, 300 PHYU and 3\% calcium decreased eggshell calcium, possibly due to increased $\mathrm{P}$ availability, which interferes with calcium and thereby reduces the quality of the shell [29]. High blood serum P levels are associated with low-quality shells, which can be attributed to the inhibited precipitation of calcium ions in the serum due to the presence of $\mathrm{P}$ ions, and at high levels, the phosphate ion competes with the carbonate ion for calcium by inhibiting the formation and development of calcite crystals [30].

\subsection{Egg Quality and Yolk Pigmentation}

There were no differences in the specific gravity of the eggs $(\mathrm{P}>0.05)$ (Table 4$)$. For phytase a similar result was found by [31]. [28] report that the specific gravity of the eggs in birds fed phosphate-deficient diets supplemented with phytase is lower than that in a control group. In contrast, [32] indicate that the specific gravity of eggs was reduced in chickens fed P-deficient diets, and the combination of $0.1 \%$ available $\mathrm{P}$ with addition of phytase improved the specific gravity.

$1.2 \% \mathrm{CA} \times 300 \mathrm{PHYU} \times 3.25 \%$ calcium and $1.2 \% \mathrm{CA} \times 0 \mathrm{PHYU} \times 3.0 \%$ calcium diet yielded the highest specific gravity values, without differences $(P>0.05)$. [33] conclude

Table 4. Yolk pigmentation and egg quality in 24- to 39-week-old laying hens supplemented with citric acid, phytase and calcium.

\begin{tabular}{|c|c|c|c|c|c|c|c|c|c|}
\hline \multirow{2}{*}{\multicolumn{2}{|c|}{ Treatments }} & \multicolumn{4}{|c|}{ Pigmentation } & \multicolumn{4}{|c|}{ Egg quality } \\
\hline & & \multicolumn{2}{|c|}{ Brightness $\left(L^{\star}\right)$} & \multicolumn{2}{|c|}{ Yellow $\left(b^{*}\right)$} & \multicolumn{2}{|c|}{ Haugh Units } & \multicolumn{2}{|c|}{ Specific Gravity } \\
\hline \multirow{2}{*}{ CA (\%) } & \multirow{2}{*}{ (PHYU/Kg) } & \multicolumn{8}{|c|}{ Calcium (\%) } \\
\hline & & 3.00 & 3.25 & 3.00 & 3.25 & 3.00 & 3.25 & 3.00 & 3.25 \\
\hline \multirow{2}{*}{0} & 0 & 61.7 & 62.3 & $40.8^{\mathrm{ab}}$ & $39.7^{\mathrm{ab}}$ & 100.5 & 100.5 & 1.084 & 1.085 \\
\hline & 300 & 61.7 & 61.5 & $41.4^{\mathrm{a}}$ & $40.4^{\mathrm{ab}}$ & 97.4 & 99.1 & 1.085 & 1.085 \\
\hline \multirow{2}{*}{0.6} & 0 & 62.0 & 61.7 & $41.8^{\mathrm{a}}$ & $39.8^{\mathrm{ab}}$ & 101.8 & 101.2 & 1.086 & 1.086 \\
\hline & 300 & 61.2 & 61.0 & $36.6^{\mathrm{b}}$ & $40.8^{\mathrm{ab}}$ & 102.8 & 100.7 & 1.087 & 1.086 \\
\hline \multirow{2}{*}{1.2} & 0 & 62.0 & 61.9 & $41.5^{\mathrm{a}}$ & $40.8^{\mathrm{ab}}$ & 100.1 & 104.6 & 1.088 & 1.087 \\
\hline & 300 & 61.8 & 60.9 & $40.8^{\mathrm{ab}}$ & $40.7^{\mathrm{ab}}$ & 99.5 & 100.5 & 1.086 & 1.088 \\
\hline \multicolumn{2}{|c|}{ SE } & \multicolumn{2}{|c|}{0.51} & \multicolumn{2}{|c|}{0.95} & \multicolumn{2}{|c|}{1.77} & \multicolumn{2}{|c|}{0.002} \\
\hline
\end{tabular}

${ }^{\mathrm{a}, \mathrm{b}}$ Averages with distinct letters between rows and columns are significantly different $(\mathrm{p}<0.05) . \mathrm{SE}=$ standard error. 
that organic acids and prebiotic, that lower $\mathrm{pH}$ in the diet and intestinal content, may have a positive effect on the quality of the shell. In contrast, [34] report that organic acids do not improve shell quality.

Haugh units were not influenced by levels of CA, phytase and/or calcium $(\mathrm{P}>0.05)$ (Table 4), however [35] indicates that acidifying substances increase Haugh units and primarily act on the $\mathrm{pH}$ and the proportions of albumen calcium and magnesium and reports that few are the substances food-related factors.

Similar results for phytase were found by [28], who detected no difference in albumen quality. In contrast, [36] in a study of 22- to 35-week-old hens fed low levels of available P (0.20\%) supplemented with phytase, found significant differences in the height of the albumen, which decreased with high levels of available P $(0.40 \%)$ and phytase.

For the yellow pigmentation of the yolk, $1.2 \% \mathrm{CA} \times 0 \mathrm{PHYU} \times 3 \%$ calcium, $0.6 \% \mathrm{CA} \times$ $0 \mathrm{PHYU} \times 3 \%$ calcium and $0 \% \mathrm{CA} \times 300 \mathrm{PHYU} \times 3 \%$ calcium improved $(\mathrm{P}<0.05)$ yellow pigmentation, with $41.5,41.8$ and 41.4 respectively, in contrast with $0.6 \% \mathrm{CA} \times$ 300 PHYU $\times 3 \%$ calcium with 36.6 (Table 4). Phytase negatively interacts with CA at low calcium levels and interferes with the yellow pigmentation of the yolk, associated with the possibly interacting effects that both compounds have on the availability of certain nutrients.

In animals that do not make good use of fat, the digestibility of carotenoid esters is low, so the efficiency of fat absorption in birds influences the rate of carotenoid deposition [37].

Research in this area involving CA is scarce, However [7] found that lipid metabolism is not modified by the addition of organic acids.

About, [38] report that extracting pigment from marigold flowers, Tagetes erecta, pre-treatment with a CA solution produces higher pigment yield and greater carotenoid retention. Moreover in some carotenoid-producing fungi, the addition of organic acids raises the content of $\beta$-carotene [39], the activity of the CA cycle and a high respiratory rate is associated with an increase in the production of compounds that improve the production of carotenoids [40].

On the other hand, there was a better response of yolk pigmentation to low levels of calcium, which is consistent with another researcher [41], who indicates that increasing the levels of calcium in the diet negatively affects the absorption of carotenoids.

\section{Conclusions}

The results of this research indicate that adding CA to the diets of laying hens during the first stage of production increases eggshell calcium content, and improves the phytase response. $1.2 \% \mathrm{CA} \times$ Phytase $\times 3.25 \%$ calcium significantly increases shell calcium by $0.56 \mathrm{~g}$. Under the conditions of the present investigation, it would imply greater resistance of the eggs to be broken in the handling from the farm to the sales centers and consumer.

Phytase interacts negatively with $0.6 \% \mathrm{CA}$ at low calcium levels to degrade the yellow pigmentation of the yolk. 


\section{References}

[1] Erdman, J. (1979) Oilseed Phytates Nutritional Implications. Journal of American Oil Chemists Society, 55, 736-740. https://doi.org/10.1007/BF02663052

[2] Simons, P., Versteegh, H., Jongbloed, A., Kemme, P., Slump, P., Wolters, M., Beudeker, R. and Verschoor, G. (1990) Improvement of Phosphorus Availability by Microbial Phytase in Broiler and Pigs. British Journal Nutrition, 64, 525-540. https://doi.org/10.1079/BJN19900052

[3] Keshavarz, K. (2000) Nonphytate Phosphorus Requirement of Layng Hens with and without Phytase on a Phase Feeding Program. Poultry Science, 79, 748-763.

https://doi.org/10.1093/ps/79.5.748

[4] Yan, F., Kersey, J., Fritts, C.A. and Waldroup, P.W. (2003) Phosphorus Requirements of Broiler Chicks Six to Nine Weeks of Age as Influenced by Phytase Supplementation. Poultry Science, 82, 294-300. https://doi.org/10.1093/ps/82.2.294

[5] Angel, R., Saylor, W., Mitchell, A., Powers, W. and Applegate, T. (2006) Effect of Dietary Phosphorus Phytase and 25-Hydroxycholecalciferol on Broiler Chicken Bone Mineralization, Litter Phosphorus, and Processing Yields. Poultry Science, 85, 1200 -1211. https://doi.org/10.1093/ps/85.7.1200

[6] Powell, S., Bidner, T. and Southern, L. (2011) Phytase Supplementation Improved Growth Performance and One Characteristics in Broilers Fed Varying Levels of Dietary Calcium. Poultry Science, 90, 604-608. https://doi.org/10.3382/ps.2010-01000

[7] Gentesse, N., Bernier, J. and Lefrancois, M. (1994) Effect of Dietary Citric Acid on Diet Metabolizability, Blood Acid-Base Balance and Abdominal Fat Deposition in Broilers. Poultry Science, 73, 34.

[8] Boling, S., Snow, J., Parsons, C. and Baker, D. (2001) The Effect of Citric Acid on the Calcium and Phosphorus Requirements of Chicks Fed Corn-Soybean Meal Diets. Poultry Science, 80, 783-788. https://doi.org/10.1093/ps/80.6.783

[9] Vargas-Rodríguez, L.M., Herrera, J.G., Morales, E.J., Suárez, M., González, M. and García, C. (2002) Citric Acid and Microbial Phytase Relative to Productive Performance and Phosphorus, Calcium and Nitrogen Excretion in Laying Hens. Técnica Pecuaria de México, 40, 169-180.

[10] Snow, J., Baker, D. and Parsons, C. (2004) Phytase, Citric Acid, and $1 \propto$-Hidroxycholecalciferol Improve Phytate Phosphorus Utilization in Chicks Fed a Corn-Soybean Meal Diet. Poultry Science, 83, 1187-1192. https://doi.org/10.1093/ps/83.7.1187

[11] Rafacz-Livingston, K., Parsons, C. and Jungk, R. (2005a) The Effects of Various Organic Acids on Phytate Phosphorus Utilization in Chicks. Poultry Science, 84, 1356-1362. https://doi.org/10.1093/ps/84.9.1356

[12] Rafacz-Livingston, K., Martinez-Amezcua, C., Parsons, C., Baker, D. and Snow, J. (2005b) Citric Acid Improves Phytate Phosphorus Utilization in Crossbed and Commercial Broiler Chicks. Poultry Science, 84, 1370-1375. https://doi.org/10.1093/ps/84.9.1370

[13] Vargas-Rodríguez, L.M., Herrera, J.G., Morales, J.E., Arcos-Garcia, J.L., Lopez-Pozos, R. and Ruelas, G. (2015) Effects of the Addition of Citric Acid, Phytase and Calcium to Diets of Laying Hens on Productive Performance, Digestibility and Mineral Excretion during the First Stage of Production. International Journal of Poultry Science, 14, 222-228. https://doi.org/10.3923/ijps.2015.222.228

[14] Quian, H., Kornegay, E. and Denbown, D. (1997) Utilization of Phytate Phosphorus and Calcium as Influenced by Microbial Phytase, Cholecalciferol, and the Calcium: Total Phosphorus Ratio in Broiler Diets. Poultry Science, 76, 37-40. https://doi.org/10.1093/ps/76.1.37 
[15] A.O.A.C. (1990) Official Methods of Analysis. 15th Edition, Association of Official Analytical Chemist, Washington DC.

[16] Parr, J. (1996) Formulating Layer Diets with Natuphosphytase. Basf Technical Symposium, Atlanta, 23 January 1996, 104-121.

[17] Elsen, E., Bohren, B. and McKean, H. (1962) The Haugh Unit as a Measure of Egg Albumen Quality. Poultry Science, 41, 1461-1468. https://doi.org/10.3382/ps.0411461

[18] Steel, R.G. and Torrie, J.H. (1988) Biostatistics: Principles and Procedures. McGraw Hill, México.

[19] SAS Institute (1990) SAS User's Guide: Statics. Version 6, 4th Edition, SAS institute Inc., Cary.

[20] Roland, D. and Brake, J. (1982) Influence of Premolt Production on Postmolt Performance with Explanation for Improvement in Egg Production Due Force Molting. Poultry Science, 61, 2473-2481. https://doi.org/10.3382/ps.0612473

[21] Ao, J., Cantor, A., Pescatore, A., Ford, M., Pierce, J. and Daawson, K. (2009) Effect of Enzyme Supplementation and Acidification of Diets on Nutrient Digestibility and Growth Performance of Broiler Chicks. Poultry Science, 88, 11-117. https://doi.org/10.3382/ps.2008-00191

[22] Esmaelipour, O., Shivazad, M., Moravej, H., Aminzadeh, S., Rezaian, M. and Van Krimpen, M. (2011) Effects of Xylanase and Citric Acid on the Performance, Nutrient Retention and Characteristics of Gastrointestinal Tract of Broilers Fed Low-Phosphorus Wheat-Based Diets. Poultry Science, 90, 1975-1982. https://doi.org/10.3382/ps.2010-01264

[23] Walk, C.L., Bedford, M.R. and McElroy, A.P. (2012) Influence of Limestone and Phytase on Broiler Performance, Gastrointestinal pH, and Apparent Ileal Nutrient Digestibility. Poultry Science, 91, 1371-1378. https://doi.org/10.3382/ps.2011-01928

[24] Bronner, F. (1998) Calcium Absorption: A Paradigm for Mineral Absorption. The Journal of Nutrition, 128, 917-920.

[25] Gifford, S. and Clydesdale, F. (1990) Interactions among Calcium, Zinc and Phytate with Three Protein Sources. Journal of Food Science, 55, 1720-1723.

https://doi.org/10.1111/j.1365-2621.1990.tb03608.x

[26] Clunies, M., Parks, D. and Lesson, S. (1992) Calcium and Phosphorus Metabolism and Eggshell Formation of Hens Fed Different Amounts of Calcium. Poultry Science, 71, 482489. https://doi.org/10.3382/ps.0710482

[27] Rama Rao, S., Raju, M., Pnad, A. and KrisnaMurth, O. (2014) Effect of Supplementing Microbial Phytase in Diets Containing Graded Concentrations of Calcium on Performance, Shell Quality and Bone Mineral Parameters in Layers. Animal Feed Science and Technolo$g y$, 193, 102-110. https://doi.org/10.1016/j.anifeedsci.2014.04.010

[28] Um, J.S. and Paik, I.K. (1999) Effects of Microbial Phytase Supplementation on Egg Production, Egg Shell Quality and Mineral Retention of Laying Hens Fed Different Levels of Phosphorus. Poultry Science, 78, 75-79. https://doi.org/10.1093/ps/78.1.75

[29] Ousterhout, L. (1980) Effects of Calcium and Phosphorus Levels on Egg Weight and Egg Shell Quality in Laying Hens. Poultry Science, 59, 1480-1484.

https://doi.org/10.3382/ps.0591480

[30] De Blas, C. and Mateos, G. (1991) Nutrition and Feeding of Laying Hens. Aedos, Barcelona.

[31] Punna, S. and Roland, D. (1999) Influence of Supplemental Microbial Phytase on First Cycle Laying Hens Fed Phosphorus-Deficient Diets from Day One of Age. Poultry Science, 78, 1407-1411. https://doi.org/10.1093/ps/78.10.1407 
[32] Gordon, R. and Roland, D. (1997) Performance of Commercial Laying Hens Fed Various Phosphorus Levels with and without Supplemental Phytase. Poultry Science, 76, 1172-1177. https://doi.org/10.1093/ps/76.8.1172

[33] Swiatkiewicz, S., Koreleski, J. and Arczewska, A. (2010) Laying Performance and Eggshell Quality in Laying Hens Fed Diets Supplemented with Prebiotic and Organic Acids. Czech Journal of Animal Science, 7, 294-306.

[34] Yesilbag, D. and Colpan, I. (2006) Effects of Organic Acid Supplemented Diets on Growth Performance, Egg Production and Quality and on Serum Parameters in Laying Hens. Revue de Médecine Vétérinaire, 175, 280-284.

[35] Sauveur, B. (1993) The Egg Consumption. Production Bases. Aedos, Barcelona.

[36] Scott, T., Kampen, R. and Silversides, F. (1999) The Effect of Phosphorus, Phytase Enzyme and Calcium on the Performance of Layers Fed Corn-Based Diets. Poultry Science, 78, 1742-1749. https://doi.org/10.1093/ps/78.12.1742

[37] Hencken, H. (1992) Chemical and Physiological Behavior of Feed Carotenoids and Their Effects on Pigmentation. Poultry Science, 71, 711-717. https://doi.org/10.3382/ps.0710711

[38] Sowbhagya, H., Sushima, S., Rastogi, N. and Naidu, M. (2013) Effect of Pretreataments on Extraction of Pigment from Marigold Flower. Journal of Food Science and Technology, 50, 122-128. https://doi.org/10.1007/s13197-011-0313-4

[39] Bhosale, P. (2004) Environmental and Cultural Stimulants in the Production of Carotenoids from Microorganisms. Applied Microbiology and Biotechnology, 6, 351-361.

https://doi.org/10.1007/s00253-003-1441-1

[40] An, G. (2001) Improved Growth of the Red Yeast. Phaffia rhodozyma (Xantophyllomices Dendrorhous) in the Presence of Tricarboxylic Acid Cycle Intermediates. Biotechnology Letters, 23, 1005-1009. https://doi.org/10.1023/A:1010523800650

[41] Vogt, H. (1981) Increasing Calcium Contents in Rations of Laying Hens with a High Rate. In: Beuving, G., Scheele, C.W. and Simons, P.C.M., Eds., Quality of Eggs, Spelderholt Institute for Poultry Research, Beekbergen, 177-185.

Submit or recommend next manuscript to SCIRP and we will provide best service for you:

Accepting pre-submission inquiries through Email, Facebook, LinkedIn, Twitter, etc.

A wide selection of journals (inclusive of 9 subjects, more than 200 journals)

Providing 24-hour high-quality service

User-friendly online submission system

Fair and swift peer-review system

Efficient typesetting and proofreading procedure

Display of the result of downloads and visits, as well as the number of cited articles

Maximum dissemination of your research work

Submit your manuscript at: http://papersubmission.scirp.org/

Or contact fns@scirp.org 